\title{
DEVELOPMENT OF EQUIPMENT FOR PRODUCING FEED MIXTURES WITH NANOPARTICLES OF SCARCE MICRONUTRIENTS
}

\author{
Andrei Belov, Vladimir Shakhov, Yuriy Ushakov, Aleksandar Putrin \\ Orenburg State Agrarian University, Russia \\ zritelmira86@yandex.ru, shahov-v@yandex.ru,1u6j1a159@mail.ru
}

\begin{abstract}
The article is devoted to the development of technology and equipment for the production of feed with nanoparticles. One of the most important conditions for successful development of animal husbandry is the creation of a rational feed base, since this item of expenditure accounts for the largest share of financial investments in the maintenance of farm animals. The physiological needs of the animal are reduced to ensuring that the food is nutritious, easily digested, readily eaten, and contains all the necessary trace elements and vitamins necessary for normal growth and development of the body. One of the most effective ways to use feedstock is primarily related to rational methods of processing it. Modern technologies of feed preparation allow preserving their nutritional value, increasing the digestibility of animals, as well as enriching them with various biologically active additives during processing. The inclusion of nanoparticles in livestock feed improves the quality of the product and improves production. The article presents the results of the study of the influence of anchor and propeller type working bodies, as well as fixed combs, on the specific energy consumption and the degree of homogeneity during the process of mixing feed raw materials with nanoparticles. The content of nanoparticles in the selected samples was determined by the method of atomic adsorption spectrometry. The need for the presence of anchor and propeller type working elements in the mixing plant, as well as a fixed comb, was proved. Since the anchor working body is slow-moving, and the propeller is fast-moving, it is shown that they need to be installed on different shafts. The proposed design of the mixer with an optimal arrangement of working bodies allows increasing the efficiency of mixing highly dispersed components and nanomaterials, and improving the quality of the finished mixture.
\end{abstract}

Keywords: mixer, energy intensity, nanoparticles, working body, feed.

\section{Introduction}

Agriculture is a branch of the economy aimed at providing the population with food and obtaining raw materials for a number of industries. One of the most important conditions for the successful development of animal husbandry is the creation of a rational feed base, since this item of expenditure accounts for the largest share of financial investments in the maintenance of farm animals. The physiological needs of the animal are reduced to the fact that the food is nutritious, easily digested, willingly eaten, and contains all the necessary trace elements and vitamins necessary for normal growth and development of the body [1-3].

One of the most effective ways to use feed raw materials is associated with rational methods of processing it. Modern technologies of feed preparation allow preserving their nutritional value, increasing animal digestibility, and enriching them with various biologically active additives during processing $[4 ; 5]$. The inclusion of nanoparticles in livestock feed improves the quality of the resulting products.

Due to the developed surface, nanoparticles have increased biological activity [6;7]. They are able to penetrate cell membranes and can act as a stable source of receipt of scarce trace elements in the animal's body. From a zootechnical point of view, it is important to introduce into the composition of the feed mixture the components provided by the diet in the required ratio and evenly distribute them throughout the entire volume. The homogeneity of the mixture ensures the same feed value for all parts of its volume. The use of heterogeneous mixtures for animal feeding significantly reduces their productive effect. It is especially important to distribute the components introduced in small quantities in the mass of the feed mixture. These components have a high feed value or biological activity. The uniform distribution of components is ensured by mixing them [8-10].

Empiricism is inherent in the mixing process and there are no universal equations describing this process. The mixing efficiency is significantly affected by the design features of the mixers, as well as the physicomechanical properties of the components of the mixture. The closer the properties of the particles are based on these characteristics, the faster their mixing occurs. Particles of components with different sizes, different densities, etc., mix longer, all other things being equal. Mixing takes longer, if any components are in the mix in small quantities [11-13]. As parameters for evaluating the 
effectiveness of mixing processes, we should use the specific energy consumption for the process and the quality indicators of the mixture.

\section{Materials and methods}

The materials used for the study were:

- feed barley that meets the requirements of GOST R 53900-2010 „Feed barley. Technical conditions";

- feed wheat that meets the requirements of GOST R 54078-2010 „Feed wheat. Technical conditions";

- feed corn that meets the requirements of GOST R 53903-2010 „Feed corn. Technical conditions";

- feed chalk that meets the requirements of GOST R 17498-72 „Gound chalk for the production of compound feeds";

- table salt that meets the requirements of GOST R 51574-2000 „Table salt food. Technical conditions";

- $\quad$ iron (Fe) nanoparticles, corresponding to TU 1791-002-36280340-2005.

- $\quad$ zinc (Zn) nanoparticles, corresponding to TU 1791-003-36280340-2008.

Mixing was carried out in a laboratory installation with removable working bodies (anchor and propeller) and the possibility of installing a comb to intensify the process. The pre-weighed components of the feed mixture were added to the mixer sequentially, after which it was switched on. Mixing was carried out within 5 minutes, since the specific energy consumption increases sharply with a longer process, and the degree of homogeneity of the mixture does not change. The mixer shaft speed and energy consumption were controlled using a multi-function frequency converter IDS-drive.

Grinding of grain raw materials was carried out on a hammer mill with a diameter of $3 \mathrm{~mm}$ sieves. Grinding of chalk and salt was carried out on a laboratory installation for ultra-fine grinding. Iron nanoparticles were pre-soaked in distilled water for 30 minutes before being added to the mixer to form a hydroxide film on their surface, which protects the nanoparticles from unwanted contact with air. This increases the chemical stability and extends the shelf life of the feed mixture. During digestion, under the influence of hydrochloric acid contained in the stomach juice of an animal, iron hydroxide turns into a water-soluble salt of iron chloride, releasing iron nanoparticles directly. Zinc nanoparticles were introduced unchanged, since they do not exhibit high chemical activity under normal conditions.

The sampling sites were determined in accordance with GOST R 57103-2016 „Specialized food products. Methods of sampling, detection and determination of the content of nanoparticles and nanomaterials in agricultural and food products", and their preparation for further research was carried out in accordance with GOST ISO 6498-2014 „Feed, compound feed. Preparation of samples for testing". The content of nanoparticles in the selected samples was determined by atomic absorption spectrometry and then the degree of uniformity of the particle distribution was calculated using the formula

$$
C_{o}=1-\frac{\sum_{i=1}^{N}\left|B_{c p}-B_{i}\right|}{B_{c p}},
$$

where $N$-number of samples taken (accepted $N=10$ );

$B_{i}$ - content of zinc nanoparticles in the $i$-th sample;

$B_{c p}$ - average content of zinc nanoparticles in each sample.

$$
B_{c p}=\frac{\sum_{i=1}^{N} B_{i}}{N} \text {. }
$$

\section{Results and discussion}

In the course of the work, the influence of the working bodies on the process of preparing a mixture of crushed feed materials consisting of: barley $-60 \%$; wheat $-30 \%$; corn $-7 \%$; feed chalk 
$-2 \%$; table salt $-0.97 \%$; iron nanoparticles $-0.02 \%$; zinc nanoparticles $-0.01 \%$ was studied. The degree of uniformity of the distribution of zinc nanoparticles and the specific energy consumption for the process were used as indicators of the efficiency of the mixing process.

Initially was identified the most optimum frequency of rotation of the shaft for anchor and propeller stirrers rotating in the same direction. The results of the study are presented in Table 1.

Table 1

Influence of the speed of the shaft with agitators on the efficiency of the mixing process

\begin{tabular}{|c|c|c|}
\hline $\begin{array}{c}\text { Type of stirrer and the rotational } \\
\text { frequency, } \mathbf{r p m}\end{array}$ & $\begin{array}{c}\text { Degree of homogeneity } \\
\text { of the mixture }\end{array}$ & $\begin{array}{c}\text { Specific energy consumption } \\
\text { for mixing, } \mathbf{~} \cdot \mathbf{t}^{\mathbf{1}}\end{array}$ \\
\hline Anchor agitator at $200 \mathrm{rpm}$ & $0.48 \pm 0.01$ & $298 \pm 2$ \\
\hline Anchor agitator at $400 \mathrm{rpm}$ & $0.68 \pm 0.01$ & $398 \pm 2$ \\
\hline Anchor agitator at $600 \mathrm{rpm}$ & $0.68 \pm 0.01$ & $458 \pm 2$ \\
\hline Propeller agitator at $800 \mathrm{rpm}$ & $0.73 \pm 0.01$ & $785 \pm 2$ \\
\hline Propeller agitator at $1000 \mathrm{rpm}$ & $0.89 \pm 0.01$ & $835 \pm 2$ \\
\hline Propeller agitator at $1200 \mathrm{rpm}$ & $0.89 \pm 0.01$ & $916 \pm 2$ \\
\hline
\end{tabular}

Based on the data obtained, the histograms are shown in Fig.1 and Fig.2.

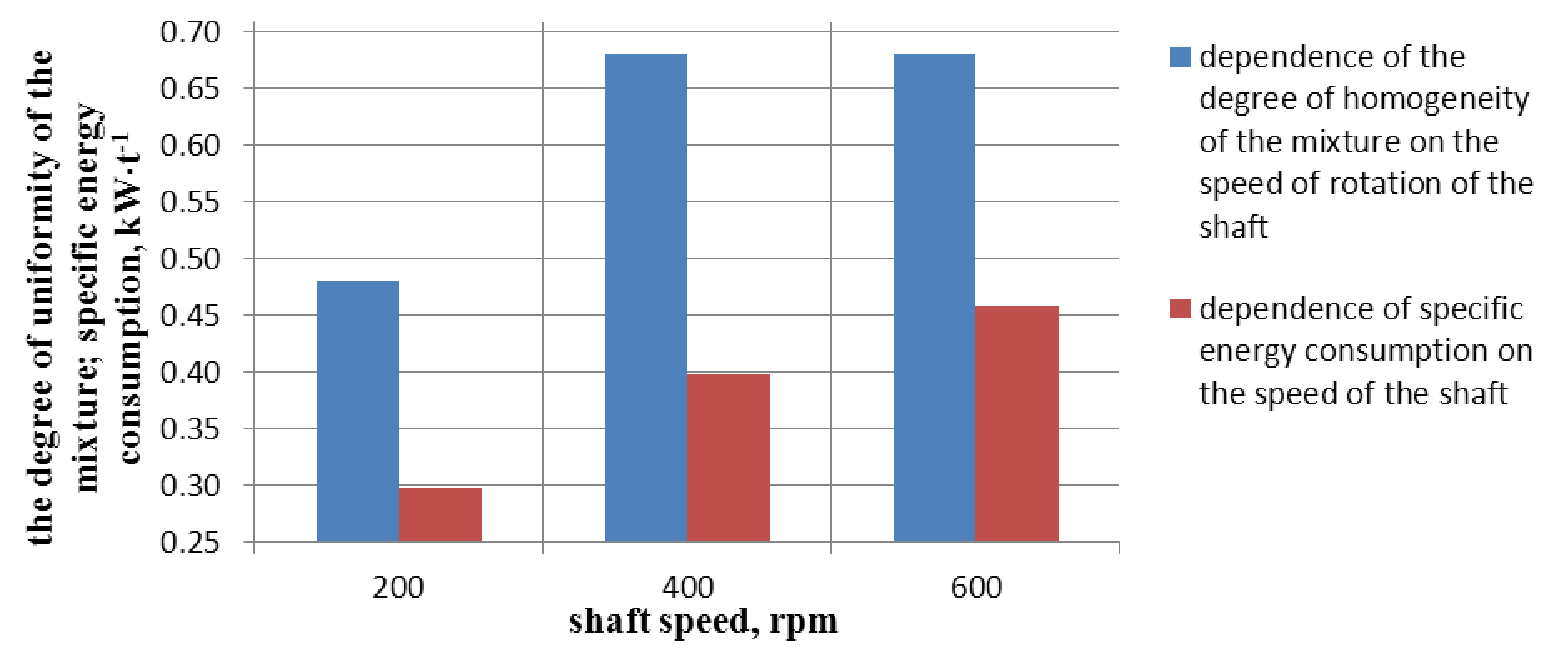

Fig. 1. Influence of the speed of rotation of the shaft with an anchor agitator on the efficiency of the mixing process

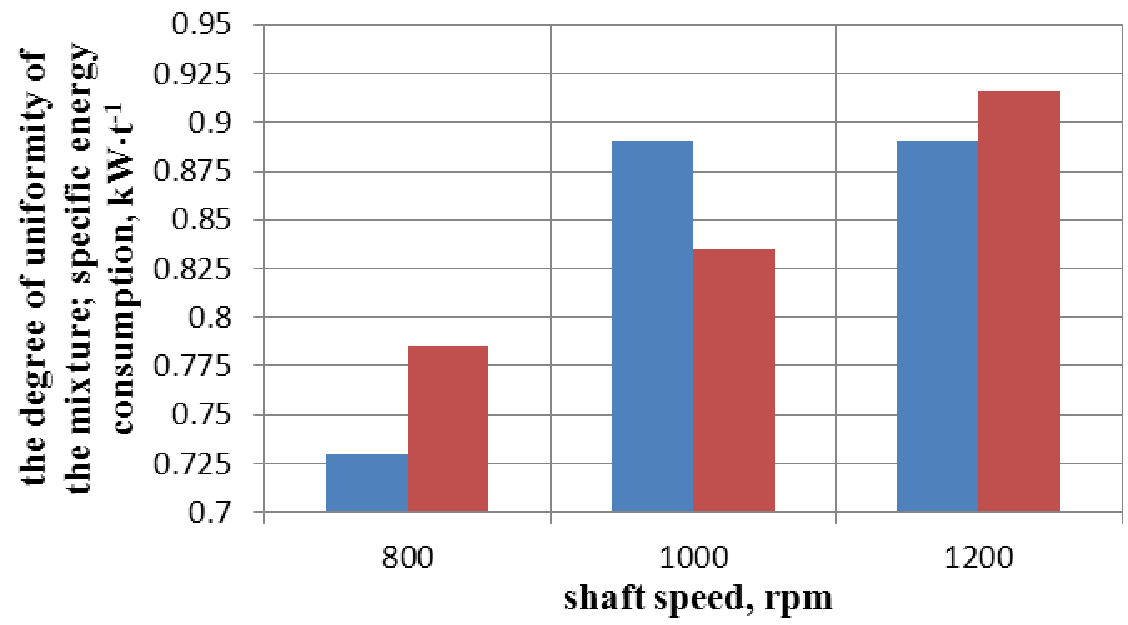

dependence of the degree of homogeneity of the mixture on the speed of rotation of the shaft

dependence of specific energy consumption on the speed of the shaft

Fig. 2. Influence of the speed of the shaft with a propeller agitator on the efficiency of the mixing process 
The histograms show that the most optimal speed of the shaft for the anchor agitator is $400 \mathrm{rpm}$, and for the propeller $1000 \mathrm{rpm}$. At higher speeds, the degree of uniformity of the mixture does not change, and the specific energy consumption increases significantly. At lower speeds, the specific energy consumption becomes less, but the degree of uniformity also decreases.

Further, the process of preparing the mixture using an anchor or propeller agitator with or without a comb was studied. The results of the study are presented in Table 2

Table 2

Influence of the layout of working bodies on the efficiency of the mixing process

\begin{tabular}{|c|c|c|}
\hline Layout of the working bodies & $\begin{array}{c}\text { Degree of homogeneity of } \\
\text { the mixture }\end{array}$ & $\begin{array}{c}\text { Specific energy consumption } \\
\text { for mixing, W. } \mathbf{t}^{-\mathbf{1}}\end{array}$ \\
\hline Anchor agitator without comb & $0.68 \pm 0.01$ & $398 \pm 2$ \\
\hline Propeller agitator without comb & $0.89 \pm 0.01$ & $835 \pm 2$ \\
\hline Anchor agitator with comb & $0.79 \pm 0.01$ & $468 \pm 2$ \\
\hline Propeller agitator with comb & $0.96 \pm 0.01$ & $935 \pm 2$ \\
\hline
\end{tabular}

The analysis of the obtained data shows that mixing using a propeller agitator with an installed comb is most intensive. The degree of uniformity in this case is $96 \%$, and the specific energy consumption is significant $-935 \mathrm{~W}$ per ton.

The use of an anchor agitator with or without a comb is not sufficient, the degree of uniformity is less than $80 \%$, but the energy consumption is significantly lower and is less than $468 \mathrm{~W}$ per ton.

The given analysis of experimental data shows that it is advisable to use both a propeller and anchor agitator when mixing, as well as to install a comb. This arrangement of working bodies allows to achieve an optimal ratio of the quality of the finished mixture and energy consumption. Since the anchor working body is slow-moving, and the propeller is fast-moving, it is necessary to install them on different shafts.

The results of the experiments determined the design of the proposed mixer. It allows to increase the mixing efficiency of highly dispersed components and improve the quality of the finished mixture. The device of the mixer is shown in Fig.3.

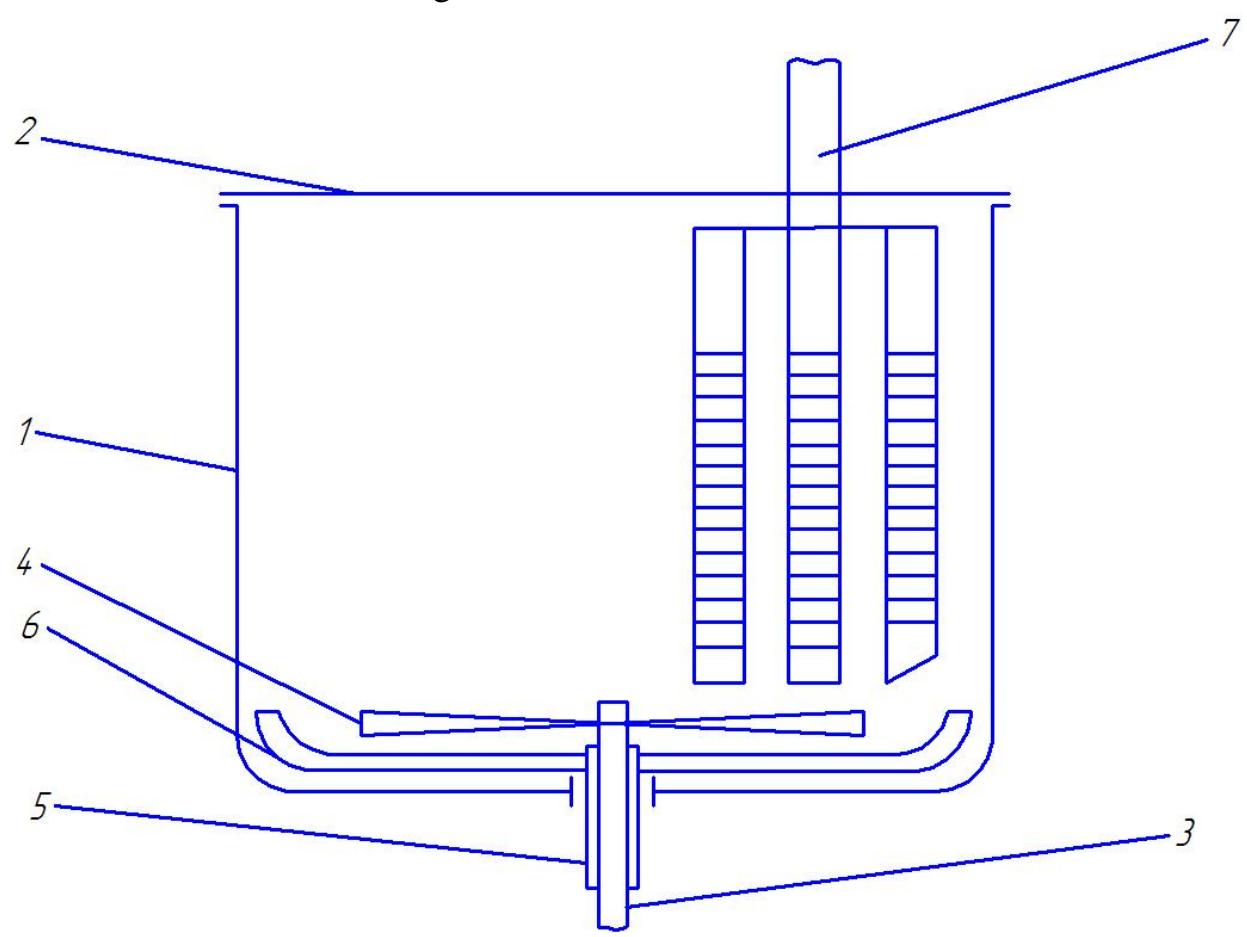

Fig. 3. Mixer: 1 - body; 2 - cover housing; 3 - shaft mixing body in the form of propeller; 4 - mixing on the propeller shape; 5 - shaft mixing on the anchor shape; 6 - mixing on the anchor form; 7 - guide rotary comb 

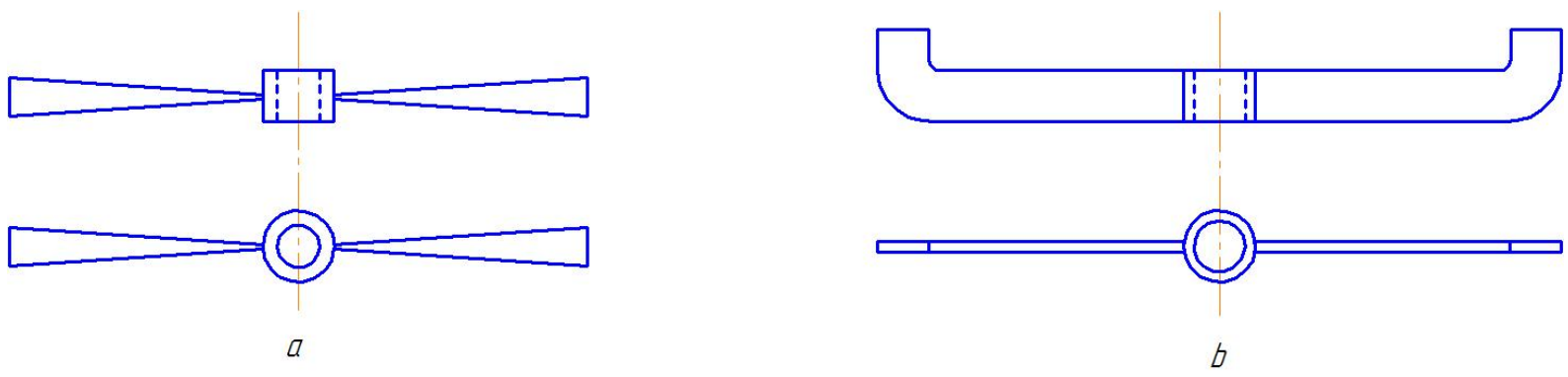

Fig. 4. Mixing bodies of the mixer: a - mixing body of the propeller form; $\mathrm{b}$ - mixing body of the anchor form

The mixer works as follows. The components are loaded into the inner space of the housing 1 closed by the cover 2 . The shaft 5 with an anchor-shaped mixing body mounted on it 6 and the shaft 3 with a mixing body mounted on it, made in the form of a propeller 4 , begin to spin and stir the contents of the substance. The resulting mixture is thrown to the walls of the housing 1, passes through the guide rotary comb 7 and is directed to the centre of the housing 1, and then again to the mixing body, made in the form of a propeller 4 .

The mixing body, made in the form of a propeller 4, provides intensive circulation of components inside the housing 1 due to the created air flow, preventing the settling of component particles at the bottom of the housing 1, and also intensifies the supply of substances to the mixing body of the anchor form 6. In turn, mixing on anchor shape 6 together with the created air flow from the mixing body in the form of propeller 4 prevents sedimentation of particles of the mixed components at the bottom of the housing 1 and transmits particles of matter kinetic energy needed to overcome gravity and friction, which leads to a fluidized condition of the mixture. Due to this, each particle acquires high mobility, and the movement of ensembles of particles is similar to the movement of liquid particles.

\section{Conclusions}

Mixing using a propeller agitator with an installed comb is most intensive. The degree of uniformity in this case is $96 \%$, and the specific energy consumption is significant - $935 \mathrm{~W}$ per ton. The use of an anchor agitator with or without a comb is not sufficient, the degree of uniformity is less than $80 \%$, but the energy consumption is significantly lower and is less than $468 \mathrm{~W}$ per ton. It is optimal to use three elements of working bodies in the mixing plant: anchor, propeller, and comb. Since the anchor working body is slow-moving, and the propeller is fast-moving, it is necessary to install them on different shafts. This design of the mixer allows to achieve a degree of uniformity of the mixture of $97 \%$ at a specific energy consumption of $805 \mathrm{~W}$ per ton.

\section{References}

[1] Сысоев В.Н. Оборудование перерабатывающих производств (Equipment for processing plants)/B.Н. Сысоев, С.А. Толпекин. - Самара: Редакционно-издательский центр самарской государственной сельскохозяйственной академии (Editorial and publishing center of the Samara state agricultural Academy), 2013. - 174 c. (In Russian).

[2] Белов А.Г. Инновационная разработка технологии и оборудования для производства экструдированных кормов с ультрадисперсными частицами (Innovative development of technology and equipment for the production of extruded feed with ultrafine particles)/A. $\Gamma$. Белов, В.А. Шахов, А.С. Путрин, А.П. Козловцев, М.И. Филатов, В.Г. Борулько // Известия Оренбургского государственного аграрного университета (Izvestia Orenburg State Agrarian University). 2019. -No. 5.(79). - C.155-158 (In Russian).

[3] Dehghan-Banadaky M., R. Corbett und M. Oba. Effects of barley grain processing on productivity of cattle. Anim. Feed Sci.Technol. 137, 2007, pp. 1-24.

[4] Popov V. P., Kolotvin A. V., Upgrading and cost efficiency of processing of grain raw materials at use of cryogenic technologies. International Scientific Journal Theoretical \& Applied Science. (10.15863/TAS 03 Volume: 71 Published: 23.03.2019).

[5] Белов А.Г. Построение математической модели процесса смешивания компонентов комбикормов (Building a mathematical model of the process of mixing feed components)/A.Г. 
Белов, В.А. Шахов, С.А. Соловьёв, В.И. Миркитанов, С.В. Золотарёв // Известия Оренбургского государственного аграрного университета (Izvestia Orenburg State Agrarian University). 2019. - No. 4(78). - C. 140-143 (In Russian).

[6] Мальцева П.П. Нанотехнологии. Наноматериалы. Наносистемная техника (Nanotechnology. Nanomaterials. Nanosystem technology)./П.П. Мальцева // - M.: Техносфера (Moscow: Technosphere), 2006. - 150 c. (In Russian).

[7] Рыбалкина M.M. Нанотехнологии для всех (Nanotechnology for everyone)/M.M. Рыбалкина // Новости нанотехнологий (Nanotechnology News Network), 2005. - 444 c. (In Russian).

[8] Ushakov Y., Shakhov V., Asmankin E., Naumov D., Theoretical study results of product flow magement process in hammer-type shredder working chamber. Engineering for Rural Development 2019, pp.185-191. (10.22616/ERDev2019.18.№231).

[9] Zhao X. Research on the New Combined Type Crusher Hammer. International Conference on Advanced Engineering Materials and Architecture Science, 2014, Vol. 488-489, pp. 1160-1164.

[10] Иванова А. П. Межуева Л. В., Гунько В. В., Пискарева Т. И., Гетманова Н. В. Инженерная геометрия в проектировании смесителей (Engineering geometry in the design of mixers). Вестник Оренбургского государственного университета (Bulletin of the Orenburg State University), No.10, 2010, pp. 138-140 (In Russian).

[11] Trupa A., Aplocina E., Degola L. Forage quality and feed intake effect on methane emissions from dairy farming. Engineering for Rural Development 2015, pp. 601-605.

[12] Khmelovskyi V., Rogach S., Tonkha O., Rosamaha Y. Quality evaluation of mixing fodder by mobile combined units. Engineering for Rural Development 2019, pp. 299-304.

DOI: 10.22616/ERDev2019.18.No.231

[13] Chkalova M., Shahov V., Pavlidis V. Effectiveness analysis of ways organizing production of combined feeds. Engineering for Rural Development 2019, pp. 462-468.

DOI: 10.22616/ERDev2019.18.N004 